\title{
OPERACINĖS KOMANDOS NARIŲ DARBO SAUGOS PRIEMONIŲ NAUDOJIMAS IR VEIKSMAI, PATYRUS MIKROTRAUMĄ
}

\author{
Agnieška Prontkelevič1,2, Viktorija Kielè ${ }^{1,2}$, Natalja Fatkulina ${ }^{2}$, Jelena Kutkauskienė ${ }^{3}$ \\ ${ }^{1}$ Vilniaus kolegijos Sveikatos priežiūros fakultetas, \\ ${ }^{2}$ Vilniaus universiteto Medicinos fakulteto Sveikatos mokslu institutas, \\ ${ }^{3}$ Mykolo Romerio universiteto Teisès mokyklos Viešosios teisès institutas
}

Raktažodžiai: mikrotrauma, operacinès komandos nariai.

\begin{abstract}
Santrauka
JAV profesinès saugos ir sveikatos agentūra nustatè, kad apie 5,6 mln. šalies sveikatos priežiūros ir kitų sričių darbuotojų yra patyrę ekspoziciją kraujo patogenais [2]. Dažniausiai sužeidimus patiria slaugytojai (37,8 proc.), rečiau - kitų specialybių sveikatos priežiūros darbuotojai. Kone pusė (44,1 proc.) visų susižeidimų ịvyksta operacinėse [12]. JAV kasmet B hepatitu užsikrečia 12000 medicinos darbuotojų, 1000 iš jų tampa lètiniais viruso nešiotojais, o 200 miršta dèl hepatito komplikacijų.

Tyrimo tikslas buvo išanalizuoti operacinès komandos narių darbo saugos priemonių naudojimą ir veiksmus patirtų mikrotraumų metu.

Metodai. Tyrimas buvo atliekamas 2017 metų rugsejjo-lapkričio mènesiais. Pagal pasirinktą temą buvo surinkta naujausia literatūra ir atlikta jos analizè. Išnagrinejjus literatūrą buvo sudaryta anketa, skirta išanalizuoti operacinès komandos narių darbo saugos priemonių naudojimo ypatumus ir veiksmus patirtu mikrotraumų metu. Prieš apklausą atliktas pilotinis tyrimas - atsitiktine tvarka išdalinta 10 anketų operacinès komandos nariams. Pilotinis tyrimas vyko nuo 2017 metų spalio 2 iki 9 dienos. Vèliau tyrimo duomenys buvo analizuojami.

Atliktas kiekybinis tyrimas, taikant anketavimo bei dokumentų analizès metodus. Imties pasirinkimo būdas netikimybinis, tikslinis.

Rezultatai. Tyrime dalyvavavę operacinès komandos nariai atsakingai laikosi darbo saugos taisyklèse išvardintų reikalavimų: daugiau nei pusè apklaustų sveikatos priežiūros specialistų (77,4 proc.) yra pasiskiepiję nuo B hepatito; po susižeidimo dauguma
\end{abstract}

operacinės komandos narių atlieka dali nustatytų standartinių veiksmų, dezinfekuoja rankas, žaizdą (80,6 proc.), pasikeičia pirštines (59,7 proc.), tačiau vengia pranešti apie incidentą atsakingam asmeniui ir nèra linkę žaizdos nusiplauti vandeniu su muilu, o vertinant operacinès personalo saugumo užtikrinimą jų darbo vietoje, sužinota, kad darbuotojai yra pakankamai aprūpinami reikiamomis asmeninèmis saugos priemonemis.

Nustatyta, kad daugiau nei pusė tyrime dalyvavusių operacinès komandos narių (62,9 proc.) bent vieną kartą per mènesị patiria mikrotraumą savo darbinèje aplinkoje: dažniausiai patiriami paviršiniai susižeidimai injekcinėmis arba siuvimo adatomis ( 50,0 proc.) reguliaraus, ịprastinio darbo metu; pagrindinè susižeidimo priežastis - skubejjimas (74,2 proc.).

Vertinant operacinès komandos narių žinias apie kraujo tyrimų atlikimą po patirtos mikrotraumos, buvo nustatyta, kad daugiau nei pusè operacinès personalo yra tinkamai informuoti apie šios procedūros eigą (66,1 proc.); susižeidimus registravo vos pusè tyrime dalyvavusių asmenų; incidentai darbe neregistruojami dèl to, jog operacinès komandos nariai mano, kad susižeidimas yra lengvas ir nevertas dèmesio (43,5 proc.); personalas neturi laisvo laiko (22,6 proc.); sveikatos priežiūros specialistai nemato tikslo to daryti dèl praeityje patirtų sužalojimų, kurie buvo užregistruoti (12,9 proc.).

\section{Ivadas}

Jungtinių Amerikos Valstijų ligų kontrolès ir prevencijos centrai apskaičiavo, kad kasmet daugiau nei 3 milijonai sveikatos priežiūros specialistų patiria ekspoziciją krauju ir kūno skysčiais dèl poodinių susižeidimų aštriais infekuotais instrumentais bei infekcijos šaltinio patekimo ant medicinos darbuotojo gleivinès. Tik JAV kasmet užregistruojama apie 


\section{4}

6 mln. susižeidimų adatomis [1].

Darbuotojams, turintiems darbe sąlytị su kito asmens krauju ir (ar kūno skysčiais), yra didžiausia rizika užsikrèsti $\mathrm{B}$ ir $\mathrm{C}$ virusiniais hepatitais, žmogaus imunodeficito virusu (toliau-ŽIV) [2]. Profesiniai sužalojimai adatomis ar kitais aštriais instrumentais dažna ir paplitusi sveikatos priežiūros specialistų problema. Šie sužalojimai didina pavojų užsikrèsti daugeliu kraujo keliu plintančių infekcinių ligų [1]. B ir C hepatito virusai bei ŽIV yra labiausiai paplitę ir pavojingi patogenai, kurie gali būti perduoti sveikatos priežiūros specialistui po sąlyčio su krauju, krauju kūno skysčiuose arba susižeidus infekuotu instrumentu darbo vietoje, pavyzdžiui, adata [3].

$\mathrm{Su}(\mathrm{si})$ žeidimai turètų būti tinkamai dokumentuojami, kad būtų galima išanalizuoti nelaimingus atsitikimus ir užregistruoti prevencines priemones [4]. Kita vertus, susižeidimų registracija vyksta labai vangiai, pranešama tik apie sunkesnius susižeidimus, arba esant didelei rizikai užsikrèsti kraujo keliu perduodamais infekcinių ligų sukèlèjais. Nustatyta, kad apie pusė (50 proc.) ir daugiau sveikatos priežiūros darbuotojų nepraneša apie poodinius susižeidimus, įvykusius darbo metu [5].

Dèl šios svarbios ir progresuojančios sveikatos priežiūros specialistų problemos atliktas šis tyrimas, norint išanalizuoti operacinės komandos narių darbo saugos priemonių naudojimą ir veiksnius patirtų mikrotraumų metu.

1 lentelė. Operacinės komandos susižeidimų neregistravimo priežastys

\begin{tabular}{|l|c|c|}
\hline $\begin{array}{l}\text { Priežastys, trukdančios pildyti pra- } \\
\text { nešimus apie susižeidimus }\end{array}$ & $\begin{array}{c}\text { Tiriamųjų } \\
\text { skaičius } \\
\text { (n=) }\end{array}$ & $\begin{array}{c}\text { Procentinė } \\
\text { išraiška } \\
\text { (\%) }\end{array}$ \\
\hline Sudėtingas registracijos protokolas & 3 & 4,8 \\
\hline Nežinau apie registracijos protokolą & 3 & 4,8 \\
\hline Pranešimas nieko nepadės & 6 & 9,7 \\
\hline Per didelis stresas pildyti pranešimą & 0 & 0,0 \\
\hline Per didelis užimtumas & 14 & $\mathbf{2 2 , 6}$ \\
\hline $\begin{array}{l}\text { Pacientas neinfekuotas B ir C hepatito } \\
\text { virusais }\end{array}$ & 4 & 6,5 \\
\hline Neužsikrėsiu & 5 & 8,1 \\
\hline $\begin{array}{l}\text { Praeityje registruota daug sužalojimų, } \\
\text { todėl neverta to daryti }\end{array}$ & 8 & $\mathbf{1 2 , 9}$ \\
\hline $\begin{array}{l}\text { Kolegų patarimas, kad neverta jau- } \\
\text { dintis }\end{array}$ & 0 & 0,0 \\
\hline Bus pažeistas konfidencialumas & 0 & 0,0 \\
\hline Aš esu infekuotas B hepatito virusu & 3 & 4,8 \\
\hline $\begin{array}{l}\text { Bijau rezultato, kuris paveiktų mano } \\
\text { karjerą }\end{array}$ & 0 & 0,0 \\
\hline $\begin{array}{l}\text { Susižeidimas yra lengvas ir nevertas } \\
\text { dėmesio }\end{array}$ & 27 & $\mathbf{4 3 , 5}$ \\
\hline Priežasčių nėra & 15 & 24,2 \\
\hline
\end{tabular}

Tyrimo objektas - operacinès komandos narių darbo saugos priemonių naudojimas ir veiksmai patirtų mikrotraumų metu.

Tyrimo tikslas - išanalizuoti operacinès komandos narių darbo saugos priemonių naudojimą ir veiksmus patirtų mikrotraumų metu.

\section{Tyrimo medžiaga ir metodai}

Atsižvelgiant ị tyrimo tikslą, laiko išteklius ir tiriamos problemos ypatumus, buvo pasirinktas ir taikytas netikimybinis tiriamujų atrankos metodas, nereikalaujantis didelio tikslumo. Neatsitiktinès imties tiriamieji buvo parinkti remiantis tiksliniu grupių formavimu. I formuojamą grupę įtraukti asmenys, priklausantys operacinès komandai [6].

Tyrimo metodai. Anketinè apklausa, kurios metu buvo naudotas iš anksto apgalvota ir parengta tyrimo anketa, padedanti susisteminti iš respondentu gaunamą informaciją. Dokumentų analizè, atrenkant informaciją iš darbuotojų ekspozicijos incidentų registracijos žurnalo. Siekta nustatyti operacinès komandos narių patiriamų mikrotraumų dažnumą bei îvertinti tiriamųų polinkị registruoti patirtus susižeidimus.

Gauti rezultatai buvo apdorojami Microsoft Office Excel 2010 programa. Atlikta atsakymų dažnio analizè. Tolydūs kintamieji duomenys apskaičiuoti vidurkiu.

\section{Tyrimo rezultatai ir jų aptarimas}

Kiekvienais metais šimtai tūkstančių sveikatos priežiūros darbuotojų patiria pavojingų kraujo patogenų poveikị. Kasdienė klinikinė veikla kelia didžiulę riziką sveikatos priežiūros specialistams susižaloti užterštomis adatomis ar kitais aštriais instrumentais [8]. Operacinès komanda nuolat dirba su dideliais kraujo kiekiais, įvairiais kūno skysčiais ir kitomis biologinėmis medžiagomis. Operacinès aplinkoje yra daug aštrių instrumentų, kurie didina poodinių susižeidimų ir užsikrètimo krauju plintančiomis virusinėmis ligomis riziką [11].

Analizuojant $\mathrm{X}$ ligoninès mikrotraumų registravimo žur-

1 pav. Operacinės komandos narių susižeidimo darbo vietoje dažnis

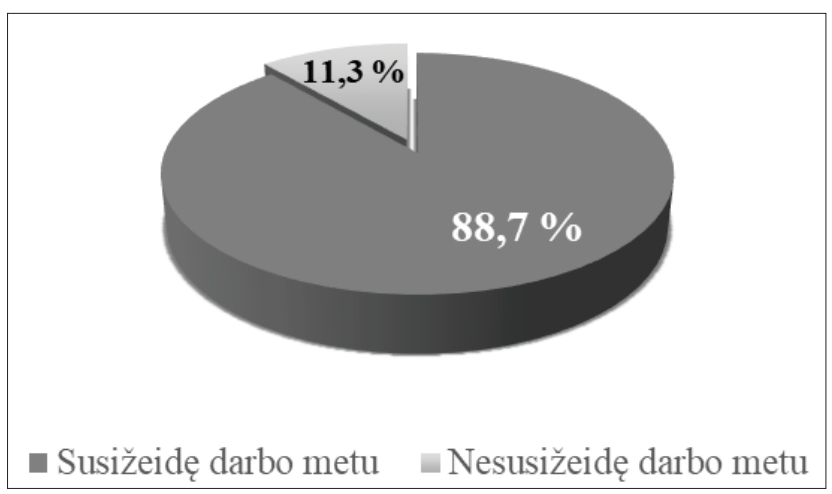


nalą sužinota, jog per pastaruosius penkerius metus buvo užregistruota 18 incidentų darbe. Dažniausiai susižeidè gydytojai chirurgai $(44,4$ proc.) ir gydytojai rezidentai (27,8 proc.). Operacinès slaugytojai bei slaugytojų padejejai pasiskirstė tolygiai (po 11,1 proc.). Rečiausiai mikrotraumas patyrè anestezijos ir intensyviosios terapijos slaugytojai (5,6 proc.).

Respondentų amžius - nuo 21 iki 60 metų. Amžiaus vidurkis buvo $M(x)=42,3$ metai. Standartinis nuokrypis (vidutinis kvadratinis nuokrypis) $\sigma=9,71$. Amžiaus moda $\mathrm{Mo}=44$ metai. Didžiąją dalį apklaustų operacinès komandos narių sudare moterys (94 proc.). Darbo operacinejje stažo vidurkis buvo $M(x)=14,7$ metų. Moda $M o=3$ metai.

Apklausos metu nustatyta, kad pusė operacinès personalui priklausančių asmenų (50,0 proc.) apie incidentą darbe pranešdavo vyresniajam slaugos administratoriui arba registravo sužeidimus.

Tyrime buvo analizuota, kokiomis asmeninèmis saugos priemonèmis operacinès komandos nariai yra aprūpinami savo darbovietejje. Išsiaiškinta, kad visi apklaustieji (100 proc.) yra aprūpinami apsauginiais drabužiais, galvos dangalais, pirštinèmis bei medicininèmis kaukèmis. Nustatytos saugos priemonès, kuriomis personalas nèra pakankamai $(41,9$ proc.) aprūpintas. Tai specialios medicininès kaukès asmenims, sergantiems bronchine astma (32,3 proc.), bei specialios pirštinès, turintiems rankų odos alergijos požymių.

Atliekant tyrimą buvo siekiama nustatyti priežastis, dèl kurių nevykdoma sužeidimų registracija gydymo įstaigose (1 lentelè).

Atlikus tyrimą, nustatyta, kad dažniausiai apie patirtas mikrotraumas vyresnysis slaugos administratorius nèra informuojamas dèl to, kad susižeidimas yra lengvas ir nevertas dėmesio (43,5 proc.); per didelis užimtumas ( 22,6 proc.); praeityje buvo daug sužalojimų ir tai buvo registruota, todèl nematau tikslo to daryti (12,9 proc.) (1 lentelè).

$\mathrm{Su}($ si)žeidimai turètų būti tinkamai dokumentuojami, kad būtų išanalizuoti nelaimingi atsitikimai ir užregistruotos

2 pav. Operacinės komandos narių susižeidimo dažnis

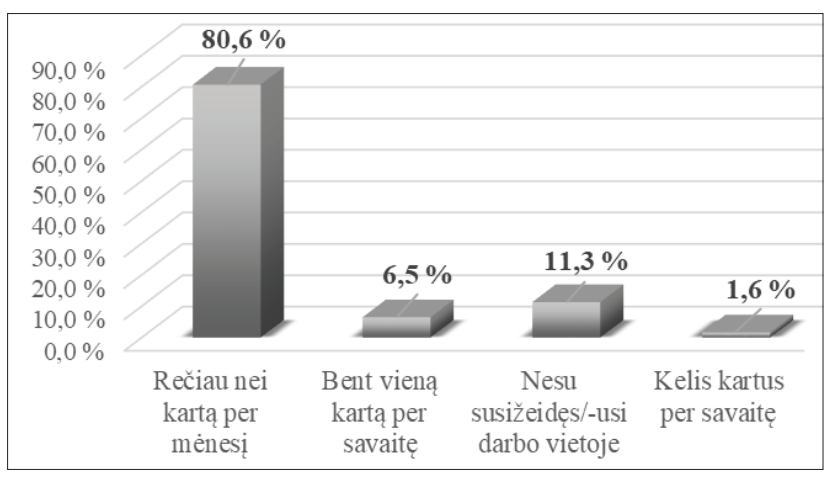

prevencinės priemonės [4], tačiau susižeidimų registracija vyksta labai vangiai, pranešama tik apie sunkesnius susižeidimus, arba esant didelei rizikai užsikrèsti kraujo keliu perduodamais infekcinių ligų sukèlëjais. Nustatyta, kad apie 50 proc. ir daugiau sveikatos priežiūros darbuotojų nepraneša apie poodinius susižeidimus, ịvykusius darbo metu [5]. Apklausos metu teirautasi, ar operacinès komandos nariai nors kartą buvo susižeidę darbo vietoje (1 pav.).

Gauti rezultatai parodè, kad dauguma $(88,7$ proc.) apklaustujų yra patyrę mikrotraumą profesinès veiklos metu (1 pav.).

Analizuojant respondentų susižeidimų dažnį buvo nustatyta, jog didžioji dauguma apklaustujų (80,6 proc.) rečiau nei vieną kartą per mènesi patiria mikrotraumą savo darbinèje aplinkoje (2 paveikslas).

Apklausos metu buvo siekiama ištirti, ar operacinès komandos nariai atlieka nustatytus standartinius veiksmus po susižeidimo (2 lentelè).

Didžioji dauguma respondentų ( 80,6 proc.) po susižeidimo dezinfekuoja rankas ir žaizdą, beveik du trečdaliai (59,7 proc.) pasikeičia pirštines. Atsižvelgiant ị tyrimo rezultatus pastebima, jog darbuotojai nèra linkę žaizdos nusiplauti su vandeniu ir muilu (33,9 proc.), pranešti apie incidentą atsakingam asmeniui ( 38,7 proc.). Tai atlieka vos trečdalis respondentų ( 2 lentelè).

Atlikdami tyrimą pasidomèjome, kokiomis darbo priemonèmis dažniausiai susižeidžia tiriamieji (3 lentelè).

Procedūros, kurias atliekant kyla didelè rizika patirti mikrotraumą yra siuvimas (60-80 proc. chirurgų susižalojo užsiūdami chirurginès operacijos vietą), netinkamas manipuliavimas aštriais instrumentais (30-70 proc.) atliekant injekcijas, siuvant žaizdas ar dedant panaudotus įrankius ị tam nepritaikytas talpas [4]. Šiame tyrime pastebèta, kad bent kartą per savaitę ir dažniau operacinès komandos nariai susižeidžia siuvimo adata (13,0 proc.). Kelis kartus per mènesị pusè tyrimo dalyvių (50,0 proc.) susižeidè injekcine adata ir kur kas rečiau - kitomis darbo priemonėmis.

2 lentelè. Susižeidus atliekami veiksmai

\begin{tabular}{|l|c|}
\hline Veiksmai & $\begin{array}{c}\text { Veiksmų } \\
\text { dažnis, \% (n) }\end{array}$ \\
\hline Apie įvykį pranešu atsakingam asmeniui & $38,7(24)$ \\
\hline Nusiplaunu žaizdą su vandeniu ir muilu & $33,9(21)$ \\
\hline Dezinfekuoju rankas, žaizdą & $80,6(50)$ \\
\hline Keičiu pirštines & $59,7(37)$ \\
\hline Sutvarkau žaizdą & $37,1(23)$ \\
\hline Kita: nesu susižeidęs & $11,3(7)$ \\
\hline Nieko nedarau & $4,8(3)$ \\
\hline
\end{tabular}


3 lentelè. Operacinès komandos narių susižeidimo darbo priemonėmis dažnis

\begin{tabular}{|c|c|c|c|c|}
\hline Darbo priemonė & $\begin{array}{c}\text { Labai dažnai } \\
\text { (kelis kartus } \\
\text { per savaitę), } \\
\% \text { (n) }\end{array}$ & $\begin{array}{l}\text { Dažnai } \\
\text { (kartą per } \\
\text { savaite), } \\
\text { \% (n) }\end{array}$ & $\begin{array}{c}\text { Kartais (ke- } \\
\text { lis kartus } \\
\text { per mėnesi), } \\
\%(n)\end{array}$ & $\begin{array}{l}\text { Niekada (né } \\
\text { karto darbo } \\
\text { metu), \% } \\
\text { (n) }\end{array}$ \\
\hline Injekcijų adata & & $1,6(1$ & $50,0(31)$ & $45,2(28)$ \\
\hline Siuvimo adata & $6,5(4)$ & $6,5(4)$ & $41,9(26)$ & $41,9(26)$ \\
\hline Skalpelis & & & $25,8(16)$ & $71,0(44)$ \\
\hline Pincetas & & & $4,8(3)$ & $91,9(57)$ \\
\hline Žirklès & & & $9,7(6)$ & $87,1(54)$ \\
\hline Aštrūs kabliukai & & & $21,0(13)$ & $75,8(47)$ \\
\hline Siuvimo viela & & & & $96,8(60)$ \\
\hline Vienadantės žnyplès & & & $6,5(4)$ & $90,3(56)$ \\
\hline Grąžtas & & & & $96,8(60)$ \\
\hline
\end{tabular}

$\underline{\text { Kita: }}$ ampulès stiklas x2, dreno troakaras, vieną kartą skalpelio peiliukas per 10 metų, prieš kelis metus siuvimo adata 3,2 proc., $n=2$.

Atlikto tyrimo duomenimis, daugiau kaip pusè $(51,6$ proc.) apklaustujjų nurodè, jog susižeidimo metu darbo priemonė, kuria susižeista, buvo infekuota, užteršta krauju.

Apskaičiuota, kad sveikatos priežiūros darbuotojai kasmet patiria apie 2 milijonus mikrotraumų, dẻl kurių kyla rizika užsikrèsti krauju plintančiomis infekcijomis: B hepatito virusu (toliau - HBV), C hepatito virusu (toliau - HCV), D hepatito virusu (toliau - HDV) arba ŽIV [9]. Tyrimo metu siekėme ịvertinti, kiek operacinèje dirbančių sveikatos priežiūros specialistų yra pasiskiepiję nuo B hepatito (3 paveikslas).

Iš daugelio krauju perduodamų ligų, B hepatitas yra ne tik labiausiai užkrečiama ir paplitusi infekcija, bet ir vienintelè, kurios galima išvengti skiepijantis [1].

Tyrimų duomenimis, įskiepijus visą vakcinos kursą (tris dozes), užtikrinama apsauga mažiausiai 15 metų, o kai kuriais atvejais ji gali trukti ir visą likusi gyvenimą [7].

Apklausos metu buvo nustatyta, kad daugiau nei pusè apklaustujų (77,4 proc.) yra pasiskiepiję nuo B hepatito. Iš nesiskiepijusių tiriamuju (22,6 proc.) keletas ( 3 proc.) buvo infekuoti HBV (3 paveikslas).

Pašalinti adatos dūrio sužeidimo infekcijos riziką sveikatos priežiūros ịstaigose yra sunku. Tačiau esama priemonių, kurios gali reikšmingai sumažinti šị pavojų. Darbuotojus galima apsaugoti pradejjus taikyti šias prevencijos ir apsaugos priemones: vengti nereikalingo aštrių instrumentų naudojimo, iggyvendinti saugų darbą užtikrinančias apsaugos priemones, įdiegti saugias darbo sistemas, nustatyti saugu medicinos prietaisų naudojimą, nedèti gaubtuvèlių ant panaudotų adatų, naudoti individualias apsaugos priemones, nemokamai skiepytis, organizuoti privalomaji darbuotojų rizikos valdymo mokymą [10].

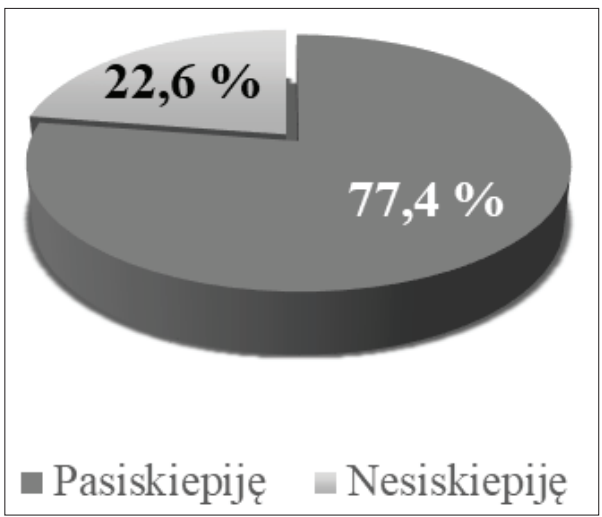

3 pav. Operacinės komandos narių skiepijimosi nuo B hepatito dažnis

\section{Išvados}

1. Nustatyta, jog dauguma operacinès komandos nariu atsakingai laikosi darbo saugos taisyklių reikalavimų: daugiau nei pusė apklaustujų yra pasiskiepiję nuo B hepatito; susižeidę dauguma operacinès komandos narių atlieka dali standartinių veiksmų (dezinfekuoja rankas, žaizdą, pasikeičia pirštines), tačiau vengia pranešti apie incidentą atsakingam asmeniui ir nèra linkę žaizdos nusiplauti su vandeniu ir muilu, o vertinant operacinès personalo saugumo užtikrinimą jų darbo vietoje, sužinota, kad darbuotojai yra pakankamai aprūpinami reikiamomis asmeninèmis saugos priemonėmis.

2. Nustatyta, kad dauguma operacinès komandos nariu bent vieną kartą per mènesi patiria mikrotraumą savo darbinėje aplinkoje: dažniausiai patiriami paviršiniai susižeidimai injekcinemis arba siuvimo adatomis reguliaraus, ịprastinio darbo metu. Per pastaruosius 12 mènesių operacinès komandos nariai dažniau patyrè vidutinio sunkumo susižeidimus; pagrindinè susižeidimo priežastis - skubejjimas.

3. Vertinant operacinès komandos žinias apie kraujo tyrimų atlikimą po patirtos mikrotraumos, nustatyta, kad daugiau nei pusė operacinès personalui priklausančių asmenų yra tinkamai informuoti apie šios procedūros eigą; susižeidimus registravo vos puse tyrime dalyvavusių asmenų; incidentai darbe neregistruojami dèl to, jog operacinès komandos nariai mano, kad susižeidimas yra lengvas ir nevertas dèmesio; personalas neturi laisvo laiko; sveikatos priežiūros specialistai nemato tikslo to daryti dèl praeityje patirtų sužalojimų, kurie buvo registruoti.

\section{Literatūra}

1. Goel V, Kumar D, Lingaiah R, Singh S. Occurrence of needle stick and injuries among health care workers of a tertiary care 
teaching hospital in North India. J Lab Physicians 2017;9(1)2025 .

https://doi.org/10.4103/0974-2727.187917

2. Budginaitė R. Per kraują plintančių infekcijų prevencijos darbo vietoje metodinès rekomendacijos. Kaunas, 2014; 44.

3. Fathi Y, Barati M, Zandiyeh M, Bashirian S. Prediction of preventive behaviors of the needle stick injuries during surgery among operating room personnel: application of the health belief model. Int J Occup Environ Med 2017;8(4):232-240. https://doi.org/10.15171/ijoem.2017.1051

4. Europos Komisija. Rizika darbuotojų sveikatai ir saugai sveikatos priežiūros sektoriuje. Prevencijos ir gerosios patirties vadovas. Liuksemburgas: Europos Sajungos leidinių biuras, 2013;275.

5. Workbook for designing, implementing and evaluating a sharps injury prevention program. https://www.cdc.gov/sharpssafety/ pdf/sharpsworkbook_2008.pdf

6. Kardelis K. Mokslinė metodologija ir metodai. Vilnius: Mokslo ir enciklopedijų leidybos centras, 2016;488.

7. Užkrečiamujų ligų ir AIDS centras. Kalendoriniai skiepai vaikams. Kaunas, 2015;26.

8. Московский городской центр профилактики и борьбы со СПИДом. ВИЧ/СПИД, профилактика. http://www.spid.ru/ spid/ru/hiv_aids_prevention.

9. Adefolalu A. Needle stick injuries and health workers: a preventable menace. Ann Med Health Sci Res. 2014;4(2):60-159. https://doi.org/10.4103/2141-9248.138046

10. Europos Sajungos Tarybos direktyva 2010/32/ES. Europos ligoninių ir sveikatos priežiūros įstaigų asociacijos ir Europos viešujų paslaugų profesinių sajungų federacijos bendrasis susitarimas dèl su(si)žeidimų aštriais instrumentais prevencijos ligoninių ir sveikatos priežiūros sektoriuje, 2010.

11. Rahmati H, Sharif F, Davarpanah MA.Surgeon's satisfaction on the use of invented needle magnet in reducing the risk of sharp injuries in the operating room. Nigerian Medical Journal 2014;55(3):220-3.

https://doi.org/10.4103/0300-1652.132044

12. International Safety Center. EPINet report for needle stick and sharp object injuries, 2015. https://internationalsafetycenter. org.

\section{USAGE OF THE WORK SAFETY MEASURES AND ACTIONS OF THE SURGICAL TEAM MEMBERS DURING EXPERIENCED MICRO TRAUMAS}

\section{A. Prontkelevič, V. Kielė, N. Fatkulina, J. Kutkauskienė}

Keywords: micro traumas, surgical team members.

Summary

The United States of America (USA) estimates that about 5.6 million people in the U.S. healthcare and other field workers have experienced exposure of blood pathogens [2]. Mostly injuries are sustained by nurses -37.8 percent, less often other specialists in healthcare. Even 44.1 percent of all injuries occur in operating rooms [12]. In the USA, 12,000 medical workers get infected with hepatitis B every year, 1,000 of them become chronic carriers of the virus and 200 die from complications of hepatitis.

The aim of this research was to analyze the usage of work safety measures and actions taken by the surgical team members when experiencing micro trauma.

Methods. The research was performed between September 2017 and November 2017. The recent literature articles were collected and analyzed according to the chosen topic. A questionnaire was prepared after the data review. The purpose of it was to analyze the usage of work safety measures and actions taken by the surgical team members when experiencing micro trauma. The pilot research has been completed before the main research - $10 \mathrm{qu}-$ estionnaires were distributed randomly to the members of the operating room team. The pilot study was conducted from October 2, 2017 until October 9. Subsequently, the research data was analyzed.

A quantitative research was carried out using questionnaire and document analysis methods. The method of sample selection: non-probabilistic, targeted.

Results. Members of the operating room team who participated in the research responsibly follow the points listed in safety regulations: more than half of the surveyed health professionals (77.4 percent) are vaccinated against hepatitis B; after an injury most members of the operating team performs part of a set of standard actions (i.e. disinfect hands / wound (80.6 percent), changing gloves (59.7 percent)). However, the interviewees avoid reporting the incident to a responsible person and are not tend to wash the wound with soap and water. In assessing the safety at workplace, it was learned that employees were adequately equipped with the necessary personal protective equipment. It was determined that more than half of the members of the operating room team who attended in the research (62.9 percent) at least once a month experience micro trauma in their work environment: most often superficial injuries are experienced by injection or sewing needles $(50.0$ percent) during regular, routine work; the main cause of injury is rush (74.2 percent).

Evaluating the knowledge of members of the operating room team about performing blood tests after experiencing micro trauma it was determined that more than half of the members of the operating room team are properly informed of the progress of this procedure (66.1 percent); injuries were reported by only half of the people in the research; incidents at work are not recorded because the interviewees believe that injury is mild and not worthy of attention (43.5 percent); personnel do not have free time (22.6 percent); healthcare professionals see no purpose in doing this due to past injuries which have been registered (12.9 percent).

Correspondence to: agnieska.pront@gmail.com

Gauta 2020-01-23 